\title{
The effects of maternal protein restriction on the growth of the rat fetus and its amino acid supply
}

\author{
William D. Rees*, Susan M. Hay, Viv Buchan, Christos Antipatis and Robert M. Palmer \\ The Rowett Research Institute, Greenburn Road, Bucksburn, Aberdeen AB21 9SB, UK
}

(Received 20 July 1998 - Revised 19 October 1998 - Accepted 30 October 1998)

\begin{abstract}
Maternal protein deficiency causes fetal growth retardation which has been associated with the programming of adult disease. The growth of the rat fetus was examined when the mothers were fed on diets containing 180,90 and $60 \mathrm{~g}$ protein $/ \mathrm{kg}$. The numbers of fetuses were similar in animals fed on the 180 and $90 \mathrm{~g}$ protein $/ \mathrm{kg}$ diets but the number was significantly reduced in the animals fed on the $60 \mathrm{~g}$ protein $/ \mathrm{kg}$ diet. The fetuses carried by the mothers fed on the $90 \mathrm{~g}$ protein/ $\mathrm{kg}$ diet were $7.5 \%$ heavier than those of mothers fed on $180 \mathrm{~g}$ protein $/ \mathrm{kg}$ diet on day 19 of gestation, but by day 21 the situation was reversed and the fetuses in the protein-deficient mothers were $14 \%$ smaller. Analysis of the free amino acids in the maternal serum showed that on day 19 the diets containing 90 and $60 \mathrm{~g}$ protein $/ \mathrm{kg}$ led to threonine concentrations that were reduced to 46 and $20 \%$ of those found in animals fed on the control $(180 \mathrm{~g} / \mathrm{kg})$ diet. The other essential amino acids were unchanged, except for a small decrease in the branched-chain amino acids in animals fed on the $60 \mathrm{~g}$ protein $/ \mathrm{kg}$ diet. Both low-protein diets significantly increased the concentrations of glutamic acid+glutamine and glycine in the maternal serum. On day 21 the maternal serum threonine levels were still reduced by about one third in the group fed on the $90 \mathrm{~g}$ protein $/ \mathrm{kg}$ diet. Dietary protein content had no effect on serum threonine concentrations in nonpregnant animals. Analysis of the total free amino acids in the fetuses on day 19 showed that feeding the mother on a low-protein diet did not change amino acid concentrations apart from a decrease in threonine concentrations to 45 and $26 \%$ of the control values at 90 and $60 \mathrm{~g}$ protein/ $\mathrm{kg}$ respectively. The results suggest that threonine is of particular importance to the proteindeficient mother and her fetuses. Possible mechanisms for the decrease in free threonine in both mother and fetuses and the consequences of the change in amino acid metabolism are discussed.
\end{abstract}

Maternal nutrition: Fetal growth: Protein restriction

In human populations strong epidemiological evidence now links low birth weight with health problems at all stages of life. Poor growth in utero has been linked to the development of type-2 (non-insulin dependent) diabetes mellitus and hypertension (Godfrey et al. 1994; Phillips et al. 1994; Barker, 1995). Fetal growth is a complex, dynamic process which is dependent on a continuous supply of nutrients from the mother. The early stages are so important that the growth of an animal undernourished in utero does not recover even when complete nutrition is restored after birth (Widdowson \& McCance, 1963; Davison \& Dobbing, 1966; Desai et al. 1996). The rat provides a convenient small animal model of this fetal programming of adult disease. The offspring of pregnant rats fed on protein-deficient diets are not only slightly smaller than controls fed on an adequate diet but also have permanent changes in the structure and function of their organs which result in reduced glucose tolerance and hypertension in adult life (Snoeck et al. 1990; Langley \& Jackson, 1994; Langley-Evans et al. 1994, 1996; Desai et al.
1995, 1996). It is not clear how a restricted maternal protein supply perturbs fetal growth. Without an increase in intake, the dietary supply of amino acids available to mother and fetus will fall with the protein content of the diet. Embryonic cells are able to respond directly to amino acid deficiency by increasing the expression of a variety of genes whose products regulate growth, differentiation and apoptosis (Fleming et al. 1998). This ability to respond to amino acid deficiency, coupled with the central role of amino acids in the metabolism of the fetus and placenta suggests that there may be a direct link between amino acid supply and fetal growth. In the rat there are two phases of protein metabolism during pregnancy. In the first, anabolic phase, there is an accretion of maternal body protein which can then be used to support fetal growth during the second, catabolic phase (Naismith \& Morgan, 1976; Remesar et al. 1987). It is not known whether this mechanism can compensate for a reduced dietary protein intake and maintain the supply of free amino acids to the fetus. In addition to protein

\footnotetext{
*Corresponding author: Dr William D. Rees, fax +44 (0) 1224 715349, email wdr@rri.sari.ac.uk
} 
synthesis, significant amounts of amino acid $\mathrm{N}$ are required for the de novo synthesis of nucleotides, further increasing the demand for those amino acids which are used as precursors, e.g. glycine and serine (Rowe \& McEwen, 1983). Because of these metabolic interconversions, a low-protein diet may not necessarily cause a deficiency of an essential amino acid but may affect the supply of nonessential amino acids (Adkins et al. 1966; Harper, 1974). We have studied maternal and fetal amino acid concentrations in rats fed on normal and protein-deficient rations to investigate changes in the availability of amino acids to the fetus. The present paper describes the free amino acid concentrations available to the developing fetus and the resulting changes in growth.

\section{Materials and methods}

\section{Experimental diets}

The experimental diets were identical to those described by Langley-Evans et al. (1996), and contained 180, 90 or $60 \mathrm{~g}$ protein $/ \mathrm{kg}$. The control, $180 \mathrm{~g}$ protein $/ \mathrm{kg}$ diet contained $(\mathrm{g} / \mathrm{kg})$ : casein 180, sucrose 213, cellulose fibre (Solkafloc) 50, maize starch 425, vitamin mix (AIN-76) 5, mineral mix (AIN-76) 20, maize oil 100, choline chloride 2, DL-methionine 5. The low-protein diets contained only 90 and $60 \mathrm{~g}$ casein $/ \mathrm{kg}$, with compensatory increases in the amounts of sucrose and maize starch $(1: 3, \mathrm{w} / \mathrm{w})$. Choline chloride and methionine were from Sigma (Poole, Dorset, UK), the other ingredients were from Special Diet Services (Witham, Essex, UK).

\section{Animals}

Two experiments were performed using female rats of the Rowett Hooded strain. They were fed on the experimental diets commencing at 6-7 weeks of age. At 2 weeks later, when weighing approximately $230-240 \mathrm{~g}$, the animals were mated with males of the same strain. Mating was confirmed by detection of a vaginal plug and this day was denoted day 0 . The female rats were maintained on the same diets throughout pregnancy. In Expt 1, three groups each of six rats were fed on one of the three diets until day 19 of pregnancy. In Expt 2, two groups each of nine rats were fed on diets containing either 180 or $90 \mathrm{~g}$ protein $/ \mathrm{kg}$ until day 21 of pregnancy; two groups of four non-pregnant control rats were fed on on the same diets. In both experiments one rat was found not to be pregnant.

Adult rats were killed by exsanguination under terminal anaesthesia with halothane (Rhone Merieux Limited, Harlow, Essex, UK), the fetuses were weighed and killed by decapitation. Maternal body weight was recorded after removal of the entire uterus and contents. All experimental procedures were approved and conducted in accordance with the UK Animals (Scientific Procedures) Act, 1986.

\section{Sample collection and analysis}

Maternal blood was collected and placed on ice for a maximum of $1 \mathrm{~h}$. The blood was centrifuged at $1000 \mathrm{~g}$ for $10 \mathrm{~min}$ at $4^{\circ}$ and the serum was stored at $-70^{\circ}$. The liver, kidney, heart and brain of eight fetuses, chosen from each mother at random, were rapidly dissected and weighed. Samples were rapidly frozen in liquid $\mathrm{N}_{2}$ and subsequently stored at $-70^{\circ}$.

Maternal serum amino acid concentrations were analysed after deproteinization with sulfosalicylic acid (final concentration $70 \mathrm{~g} / \mathrm{l})$. The fetus contained insufficient blood for amino acid analysis and therefore one whole fetus from each mother was homogenized in $3 \mathrm{ml} 2 \mathrm{M}-\mathrm{HClO}_{4}$ and following centrifugation the supernatant fraction was used for analysis. Norleucine $(100 \mathrm{nmol} / \mathrm{ml})$ was added to all samples to act as an external standard. Samples were analysed using a Waters Pico-Tag system (Waters Corp., Milford, MA, USA) using pre-column derivatization with phenylisothiocyanate. Derivatives were separated on a C18 column using a sodium acetate-acetonitrile gradient suitable for the analysis of physiological fluids. The amino acid derivatives were detected by u.v. absorption at $254 \mathrm{~nm}$ and results calculated using the Waters Millennium software package.

Liver protein estimation was performed by the method of Lowry et al. (1951), RNA was measured by the method of Ashford \& Pain (1986) and DNA by the method of Burton (1956).

\section{Statistics}

Mean values were calculated for all the pups and placentas. Previous work with the same strain of rats has not shown any correlation between fetal number and fetal weight (Palmer et al. 1996). Fetal organs were dissected from up to eight fetuses chosen at random from each mother. The data in Table 2 were subjected to Student's $t$ test. Data from Expt 1 (Tables 1, 3, 4 and 5) were analysed by one-way ANOVA followed by a Tukey multiple comparison test. Data were processed using the Instat statistical package (Graph Pad Software Inc., San Diego, CA, USA). Data in Table 6 were analysed by two-way ANOVA (diet $v$. pregnancy) using the Genstat 5 statistical package (Genstat 5 release 3.1, Committee of the Statistics Department, Rothampstead Experimental Station, Harpenden, Herts., UK).

\section{Results}

The growth increments of the mother, fetus, and the major fetal organs were measured in two separate experiments, terminating on days 19 and 21 of pregnancy (total gestation time in the rat is $22.5 \mathrm{~d}$ ). In the first experiment animals were fed on diets containing 180, 90 and $60 \mathrm{~g}$ protein $/ \mathrm{kg}$ and slaughtered on day 19 of gestation (Table 1). The maternal food intakes were not significantly different on the three diets, $20 \cdot 1(\mathrm{SE} 0.6), \quad 21 \cdot 2(\mathrm{SE} 0.8)$ and $19 \cdot 8(\mathrm{SE} 0.7) \mathrm{g} / \mathrm{d}$ respectively during the $19 \mathrm{~d}$ experimental period. In the second experiment animals were fed on diets containing 180 or $90 \mathrm{~g}$ protein $/ \mathrm{kg}$ and slaughtered on day 21 (Table 2). In this case the food consumption values were $19.0(\operatorname{SE} 0.5) \mathrm{g} / \mathrm{d}$ and $19 \cdot 2(\mathrm{SE} 0 \cdot 3) \mathrm{g} / \mathrm{d}$ respectively. The reduction in the protein content did not significantly affect the weight of the dams at slaughter on day 19 or day 21 (Tables 1 and 2). The numbers of fetuses carried by each mother were similar in rats given diets with 180 and $90 \mathrm{~g}$ protein $/ \mathrm{kg}$ but were reduced by $40 \%$ in rats given only $60 \mathrm{~g}$ protein $/ \mathrm{kg}$ in the diet. There was no evidence for an increase in the number of 
Table 1. Maternal, placental, fetal and fetal organ weights* on day 19 of pregnancy in rats fed on diets containing 180 (control), 90 or $60 \mathrm{~g}$ protein $/ \mathrm{kg} \dagger$

(Mean values with their standard errors)

\begin{tabular}{|c|c|c|c|c|c|c|}
\hline \multirow[t]{2}{*}{ Dietary protein $(\mathrm{g} / \mathrm{kg}) \ldots$} & \multicolumn{2}{|c|}{180} & \multicolumn{2}{|c|}{90} & \multicolumn{2}{|c|}{60} \\
\hline & Mean & SE & Mean & SE & Mean & SE \\
\hline No. of dams & 6 & & 5 & & 5 & \\
\hline Maternal weight at mating $(\mathrm{g})$ & 241 & 3 & 240 & 6 & 234 & 3 \\
\hline Maternal weight at $19 \mathrm{~d}$ pregnant $(\mathrm{g})$ & 290 & 10 & 282 & 13 & 274 & 6 \\
\hline Fetuses/mother & $14 \cdot 0^{\mathrm{a}}$ & 0.6 & $15 \cdot 0^{\mathrm{ab}}$ & 0.3 & $9 \cdot 4^{\mathrm{b}}$ & 0.7 \\
\hline Total no. of fetuses & 86 & & 68 & & 53 & \\
\hline Fetal weight $(\mathrm{g})$ & $1.85^{\mathrm{a}}$ & 0.04 & $1.99^{b}$ & 0.06 & $1.90^{\mathrm{a}}$ & 0.04 \\
\hline Placental weight $(\mathrm{g})$ & 0.44 & 0.01 & 0.41 & 0.01 & 0.43 & 0.01 \\
\hline Placenta: fetus & 0.24 & & 0.21 & & 0.23 & \\
\hline \multirow{2}{*}{\multicolumn{7}{|c|}{ Organ weights (mg) }} \\
\hline & & & & & & \\
\hline Liver & $142^{\mathrm{a}}$ & 6 & $159^{b}$ & 14 & $150^{\mathrm{ab}}$ & 10 \\
\hline Kidney & $13 \cdot 1^{\mathrm{a}}$ & 0.9 & $14.9^{b}$ & 1.5 & $13 \cdot 9^{\mathrm{ab}}$ & 1.0 \\
\hline Heart & $9 \cdot 6$ & 0.4 & 9.6 & 0.8 & 9.8 & 0.7 \\
\hline Brain & 102 & 6 & 108 & 7 & 102 & 6 \\
\hline \multicolumn{7}{|l|}{ Organ weights ( $\%$ total weight) } \\
\hline Liver & $7 \cdot 69$ & $0 \cdot 13$ & 7.98 & 0.17 & 7.86 & 0.15 \\
\hline Kidneys & $0.71^{a}$ & 0.01 & $0.74^{b}$ & 0.01 & $0.73^{a b}$ & 0.01 \\
\hline Heart & 0.52 & 0.01 & 0.48 & 0.02 & 0.52 & 0.01 \\
\hline Brain & 5.53 & 0.09 & 5.49 & 0.12 & 5.54 & 0.08 \\
\hline
\end{tabular}

${ }^{a, b}$ Mean values within a row not sharing a common superscript letter were significantly different, $P<0.05$ (one-way ANOVA).

* All the fetuses and placentas were weighed, and fetal organs were dissected from up to eight fetuses, chosen at random, from each dam.

†For details of diets and procedures, see p. 244.

resorption sites which suggested that there was either a very early failure in development or a decrease in the number of embryos which had implanted.

On day 19 the fetuses of the $90 \mathrm{~g}$ protein $/ \mathrm{kg}$ group were approximately $7.5 \%$ heavier than those of the control group. There were also significant increases in the weight of the liver $(11.9 \%)$ and kidneys $(13.7 \%)$ but not the heart or brain (Table 1). When the organ weights were expressed as a percentage of the total fetal weight, the kidneys were significantly heavier, implying that the change in fetal growth was not uniform. There was a similar but non-significant trend in the group fed on the $60 \mathrm{~g}$ protein $/ \mathrm{kg}$

Table 2. Maternal, placental, fetal and fetal organ weights $†$ on day 21 of pregnancy in rats fed on diets containing 180 or $90 \mathrm{~g}$ protein $/ \mathrm{kg} \ddagger$

(Mean values with their standard errors)

\begin{tabular}{|c|c|c|c|c|}
\hline \multirow[t]{2}{*}{ Dietary protein $\mathrm{g} / \mathrm{kg} \ldots$} & \multicolumn{2}{|c|}{180} & \multicolumn{2}{|c|}{90} \\
\hline & Mean & SE & Mean & SE \\
\hline No. of dams & 8 & & 9 & \\
\hline Maternal weight at mating $(\mathrm{g})$ & 228 & 3 & 229 & 3 \\
\hline Maternal weight at $21 \mathrm{~d}$ pregnant $(\mathrm{g})$ & 286 & 6 & 271 & 5 \\
\hline Fetuses/mother & $13 \cdot 0$ & 1.7 & 14.9 & 0.2 \\
\hline Total no. of fetuses & 104 & & 134 & \\
\hline Fetal weight $(\mathrm{g})$ & $4 \cdot 13$ & 0.05 & $3.56^{\star \star \star}$ & 0.04 \\
\hline Placental weight $(\mathrm{g})$ & 0.59 & 0.01 & $0.53^{* * *}$ & 0.01 \\
\hline Placenta : fetus & 0.14 & 0.01 & 0.15 & 0.01 \\
\hline Total no. of fetal organs weighed & 62 & & 72 & \\
\hline \multicolumn{5}{|l|}{ Organ weights $(\mathrm{mg})$} \\
\hline Liver & 258 & 5 & $212^{* * *}$ & 7 \\
\hline Kidneys & 38.7 & 0.7 & $32 \cdot 0^{* \star *}$ & 0.4 \\
\hline Heart & 18.8 & 0.4 & $17 \cdot 2^{* * *}$ & 0.4 \\
\hline Brain & 167 & 3 & $148^{\star \star *}$ & 2 \\
\hline \multicolumn{5}{|l|}{ Organ weight (\% total weight) } \\
\hline Liver & $6 \cdot 10$ & 0.09 & $5 \cdot 82^{*}$ & 0.08 \\
\hline Kidneys & 0.92 & 0.01 & 0.89 & 0.01 \\
\hline Heart & 0.45 & 0.01 & $0.48^{* * *}$ & 0.01 \\
\hline Brain & 3.98 & 0.06 & $4 \cdot 21^{*}$ & 0.07 \\
\hline
\end{tabular}

Mean values were significantly different from those for the $180 \mathrm{~g} / \mathrm{kg}$ group: ${ }^{\star} P<0.05$, ${ }^{\star \star \star} P<0.001$ (Student's $t$ test).

† All the fetuses and placentas were weighed, fetal organs were dissected from up to eight fetuses, chosen at random, from each dam.

‡For details of diets and procedures, see p. 244. 
Table 3. Composition, at day 19 of pregnancy, of livers from fetuses of rats fed on diets containing 180,90 or $60 \mathrm{~g}$ protein $/ \mathrm{kg}^{*}$

(Mean values, with their standard errors, of six ( $180 \mathrm{~g} / \mathrm{kg}$ diet) or five (90 and $60 \mathrm{~g} / \mathrm{kg}$ diets) values, each being the mean of two determinations (two fetuses from each dam))

\begin{tabular}{|c|c|c|c|c|c|c|}
\hline \multirow[t]{2}{*}{ Dietary protein $(\mathrm{g} / \mathrm{kg}) \ldots$} & \multicolumn{2}{|c|}{180} & \multicolumn{2}{|c|}{90} & \multicolumn{2}{|c|}{60} \\
\hline & Mean & SE & Mean & SE & Mean & SE \\
\hline Fetal liver protein (mg) & 13.02 & 0.83 & 14.93 & 0.97 & 13.62 & 1.04 \\
\hline Protein (mg/g of wet weight) & $92 \cdot 3$ & $6 \cdot 4$ & 91.8 & 1.8 & $86 \cdot 8$ & 4.3 \\
\hline RNA (mg) & 1.19 & 0.05 & 1.34 & 0.03 & 1.31 & 0.07 \\
\hline RNA ( $\mu \mathrm{g} / \mathrm{mg}$ protein) & 8.52 & 0.43 & $8 \cdot 20$ & 0.39 & 8.63 & 0.31 \\
\hline DNA (mg) & 0.89 & 0.06 & 1.01 & 0.05 & 1.06 & 0.05 \\
\hline DNA ( $\mu \mathrm{g} / \mathrm{mg}$ protein) & 6.52 & 0.58 & $6 \cdot 31$ & 0.61 & 7.09 & 0.49 \\
\hline RNA: protein & 0.093 & 0.002 & 0.090 & 0.002 & 0.092 & 0.001 \\
\hline DNA: RNA & 0.674 & 0.058 & 0.815 & 0.045 & 0.837 & 0.041 \\
\hline DNA: protein & 0.070 & 0.006 & 0.079 & 0.006 & 0.090 & 0.009 \\
\hline
\end{tabular}

${ }^{*}$ For details of diets and procedures, see p. 244.

diet (Table 1). The 90 and 60 protein/ $\mathrm{kg}$ diets did not change the weight of the placentas and therefore the ratio placenta: fetus was reduced because of the increase in fetal weight.

By day 21 the fetuses from the mothers fed on the $90 \mathrm{~g}$ protein $/ \mathrm{kg}$ diet were $14 \%$ lighter than those of the control group (Table 2). Between days 19 and 21 the weight of the control fetuses had increased so that it was more than double that at day $19(+123 \%)$. In comparison, fetuses from mothers fed on $90 \mathrm{~g}$ protein $/ \mathrm{kg}$ diet had increased in weight by $78 \%$. Table 2 shows that by day 21 the weights of all of the organs were significantly reduced, the liver by $18 \%$, the kidneys by $17 \%$, the heart by $8.5 \%$ and the brain by $11 \%$ in the group fed on $90 \mathrm{~g}$ protein $/ \mathrm{kg}$ when compared with the control group. However, when these data were expressed as a proportion of the total fetal weight, the liver was a significantly smaller part of the whole fetus whereas the heart and brain were larger. The placentas were also significantly smaller in the group fed on the $90 \mathrm{~g}$ protein/ $\mathrm{kg}$ diet. Reductions in the placental and fetal weights resulted in an unchanged placental: fetus ratio.

Table 3 shows the tissue composition of the fetal livers on day 19. The protein content of the maternal diet did not affect the tissue protein content as a percentage of the wet weight. There were small increases in total RNA and DNA contents $(P=0.107$ and $P=0.091$ respectively) in the animals fed on the low-protein diets. The DNA content was increased by $13 \%$ in fetuses from mothers fed on the $90 \mathrm{~g}$ protein $/ \mathrm{kg}$ diet and by $19 \%$ in those fed on the $60 \mathrm{~g}$ protein $/ \mathrm{kg}$ diet.

The free amino acid concentrations in the maternal serum on day 19 of pregnancy are shown in Table 4. The lowprotein diets increased the maternal serum concentrations of glutamic acid + glutamine and glycine, but decreased the concentration of the branched-chain amino acids (valine, isoleucine and leucine) and most markedly threonine

Table 4. Amino acid concentrations $(\mathrm{nmol} / \mathrm{ml})$, at day 19 of pregnancy, in the serum of rat dams fed on diets containing 180,90 or $60 \mathrm{~g}$ protein $/ \mathrm{kg}^{*}$

(Mean values with their standard errors)

\begin{tabular}{|c|c|c|c|c|c|c|}
\hline \multirow[t]{2}{*}{$\begin{array}{l}\text { Dietary protein }(\mathrm{g} / \mathrm{kg}) \ldots \\
n \ldots\end{array}$} & \multicolumn{2}{|c|}{$\begin{array}{c}180 \\
6\end{array}$} & \multicolumn{2}{|c|}{$\begin{array}{c}90 \\
5\end{array}$} & \multicolumn{2}{|c|}{$\begin{array}{c}60 \\
6\end{array}$} \\
\hline & Mean & SE & Mean & SE & Mean & SE \\
\hline Aspartic acid+asparagine & 155 & 15 & 206 & 14 & 194 & $\overline{3}$ \\
\hline Glutamic acid + glutamine & $669^{a}$ & 70 & $1102^{\mathrm{b}}$ & 88 & $1163^{b}$ & 98 \\
\hline Histidine & 48 & 4 & 53 & 6 & 51 & 7 \\
\hline Serine & 390 & 31 & 435 & 32 & 433 & 41 \\
\hline Glycine & $148^{\mathrm{a}}$ & 11 & $211^{b}$ & 13 & $212^{b}$ & 24 \\
\hline Threonine & $804^{a}$ & 77 & $369^{b}$ & 40 & $163^{c}$ & 12 \\
\hline Alanine & 918 & 133 & 975 & 149 & 1149 & 198 \\
\hline Arginine & 133 & 9 & 184 & 28 & 176 & 17 \\
\hline Valine & $237^{\mathrm{a}}$ & 8 & $175^{\mathrm{ab}}$ & 11 & $160^{\mathrm{b}}$ & 8 \\
\hline Isoleucine & $130^{\mathrm{a}}$ & 4 & $104^{a b}$ & 6 & $92^{b}$ & 6 \\
\hline Leucine & $161^{\mathrm{a}}$ & 10 & $123^{\mathrm{ab}}$ & 8 & $103^{b}$ & 3 \\
\hline Methionine & 106 & 1 & 107 & 6 & 119 & 5 \\
\hline Tyrosine & 78 & 2 & 72 & 4 & 75 & 10 \\
\hline Phenylalanine & 74 & 7 & $7 \overline{9}$ & 8 & 73 & 4 \\
\hline Tryptophan & 70 & 11 & 60 & 12 & 73 & 8 \\
\hline Lysine & 1130 & 101 & 1212 & 88 & 1103 & 60 \\
\hline
\end{tabular}

$\overline{a, b, c}$ Mean values within a row not sharing a common superscript letter were significantly different, $P<0.05$ (ANOVA). ${ }^{*}$ For details of diets and procedures, see p. 244. 
Table 5. Free amino acid concentrations (nmol/g fetal weight), on day 19 of pregnancy, in fetuses from rat dams fed on diets containing 180,90 or $60 \mathrm{~g}$ protein $/ \mathrm{kg}^{*}$

\begin{tabular}{|c|c|c|c|c|c|c|}
\hline \multirow[t]{2}{*}{$\begin{array}{l}\text { Dietary protein }(\mathrm{g} / \mathrm{kg}) \ldots \\
n \ldots\end{array}$} & \multicolumn{2}{|c|}{$\begin{array}{c}180 \\
5\end{array}$} & \multicolumn{2}{|c|}{$\begin{array}{c}90 \\
4\end{array}$} & \multicolumn{2}{|c|}{$\begin{array}{c}60 \\
2\end{array}$} \\
\hline & Mean & SE & Mean & SE & Mean & SE \\
\hline Aspartic acid & 39 & 3 & 33 & 7 & 45 & $\overline{1}$ \\
\hline Glutamic acid + glutamine & 201 & 16 & 171 & 27 & 181 & 10 \\
\hline Histidine & 30 & 4 & 37 & 4 & 30 & 7 \\
\hline Serine & 501 & 17 & 529 & 60 & 586 & 43 \\
\hline Glycine & 827 & 56 & 836 & 82 & 1026 & 62 \\
\hline Threonine & $678^{a}$ & 52 & $302^{b}$ & 26 & $175^{c}$ & 23 \\
\hline Alanine & 1223 & 57 & 1368 & 195 & 1390 & 68 \\
\hline Arginine & 57 & 6 & 65 & 3 & 72 & 2 \\
\hline Proline & 276 & 12 & 269 & 38 & 292 & 16 \\
\hline Valine & 229 & 9 & 212 & 16 & 221 & 4 \\
\hline Isoleucine & 99 & 6 & 86 & 7 & 91 & 1 \\
\hline Leucine & 221 & 9 & 209 & 20 & 209 & 18 \\
\hline Methionine & 31 & 7 & 28 & 6 & 51 & 7 \\
\hline Tryptophan & 107 & 28 & 97 & 38 & 74 & 12 \\
\hline Phenylalanine & 158 & 18 & 175 & 21 & 209 & 18 \\
\hline Lysine & 1053 & 112 & 1091 & 75 & 1117 & 14 \\
\hline
\end{tabular}

${ }^{a, b, c}$ Mean values within a row not sharing a common superscript letter were significantly different, $P<0.05$ (ANOVA).

${ }^{*}$ For details of diets and procedures, see p. 244.

(Table 4). Because of the difficulties associated with obtaining sufficient fetal blood for the amino acid analysis, the total free pools of the fetus were measured (Table 5). Changes in the concentration of glutamic acid+glutamine, glycine and the branched-chain amino acids were confined to the maternal serum and not observed in the fetus, whilst the change in threonine occurred in both the maternal serum and the fetal free pool. The concentrations of threonine in the maternal serum were reduced to 46 and $20 \%$ of the control value and in the fetus to 45 and $26 \%$ of the control value at 90 and $60 \mathrm{~g}$ dietary protein $/ \mathrm{kg}$ respectively. With the exception of threonine, there were no significant dietinduced changes in the concentrations of any other amino acids in the fetus (Table 5).

The data in Table 6 compare the serum amino acid profiles of non-pregnant rats with those found on day 21 of pregnancy. At both 180 and $90 \mathrm{~g} / \mathrm{kg}$ levels of dietary protein there was an increase in the concentration of lysine in pregnancy ( $90 \%$ and $54 \%$ respectively). Branched-chain amino acids were decreased whilst glycine was increased as a result of pregnancy. Again, as on day 19 the amino acid most affected on day 21 was threonine which showed a significant decrease due to pregnancy and a significant interaction between pregnancy and diet (Table 6). This decline in free threonine was also observed in the fetus where the concentration fell from 676 (SE 74) nmol/g in the group fed on $180 \mathrm{~g}$ protein/kg to 468 (SE 46) nmol/g in the group fed on $90 \mathrm{~g}$ protein $/ \mathrm{kg}$ (both $n 8 ; P>0.05$ ). A comparison of the values from the animals fed on the $180 \mathrm{~g}$ protein/kg diet on day 21 with those found on day 19 (Table 4) shows that the majority of amino acids were unchanged, the only exception was threonine where the levels were nearly halved.

\section{Discussion}

The interaction between maternal nutrition and the growth of the fetus is poorly understood. The present study shows that a reduction in the protein content of the maternal diet does not produce a generalized reduction in the amino acid supply via the serum. Free lysine concentrations in the mother are approximately doubled as a result of pregnancy, yet this increase still occurs when the protein content of the diet is reduced to 90 or even $60 \mathrm{~g} / \mathrm{kg}$. It is probable that any dietary deficit is made up by the mobilization of maternal proteins, maintaining both fetal and maternal lysine concentrations. The more extreme reduction in dietary protein to $60 \mathrm{~g} / \mathrm{kg}$ does decrease the fetal number, thus reducing the total fetal load. Whilst the concentrations of most essential amino acids are maintained, there are highly significant decreases in free threonine in both mother and fetuses when the pregnant animals are fed on low-protein diets. The changes in threonine concentrations occur only in the pregnant animals; feeding the $90 \mathrm{~g}$ protein $/ \mathrm{kg}$ diet to nonpregnant female rats had no effect on serum threonine, showing that this level of protein is not deficient with regard to threonine requirements of the non-pregnant animal.

Our present data show that the growth of the fetuses had already changed by day 19 of gestation but paradoxically, growth had increased in the protein-deficient group. Langley-Evans et al. (1996) showed a similar early increase in the growth of the fetuses in pregnant rats of the Wistar strain fed on an identical diet. The data in Table 3 are not conclusive but may suggest that the small increase in the total DNA content reflects an increase in the number of cells. It is probable that this is also the case for other fetal organs and accounts for the increase in total fetal weight. However, the results clearly show that the highly significant fall in the threonine concentrations does not reduce fetal growth before day 19, indicating that the total amino acid supply, and in particular threonine, is not limiting for protein synthesis. Between days 19 and 21 the growth of the fetuses in the groups fed on the low-protein diets was 
Table 6. Amino acid concentrations $(\mathrm{nmol} / \mathrm{ml})$ in the serum of non-pregnant rats and pregnant rats (at $21 \mathrm{~d}$ of pregnancy) fed on diets containing $180 \mathrm{~g}$ protein $/ \mathrm{kg} \dagger$

(Mean values with their standard errors)

\begin{tabular}{|c|c|c|c|c|c|c|c|c|c|c|c|}
\hline \multirow{3}{*}{$\begin{array}{l}\text { Dietary protein }(\mathrm{g} / \mathrm{kg}) \ldots \\
n \ldots\end{array}$} & \multicolumn{4}{|c|}{ Non-pregnant } & \multicolumn{4}{|c|}{ Pregnant } & \multicolumn{3}{|c|}{$\begin{array}{l}\text { Statistical significance } \\
\text { of effect of treatments }\end{array}$} \\
\hline & \multicolumn{2}{|c|}{$\begin{array}{c}180 \\
4\end{array}$} & \multicolumn{2}{|c|}{$\begin{array}{c}90 \\
4\end{array}$} & \multicolumn{2}{|c|}{$\begin{array}{c}180 \\
8\end{array}$} & \multicolumn{2}{|c|}{$\begin{array}{c}90 \\
9\end{array}$} & \multirow[b]{2}{*}{ Pregnancy } & \multirow[b]{2}{*}{ Diet } & \multirow[b]{2}{*}{ Interactior } \\
\hline & Mean & SE & Mean & SE & Mean & SE & Mean & SE & & & \\
\hline $\begin{array}{l}\text { Aspartic acid + asparagine } \\
\text { Glutamic acid }\end{array}$ & 129 & 19 & 162 & 27 & 195 & 10 & 209 & 8 & - & - & - \\
\hline Serine & 332 & 63 & 420 & 99 & 349 & 22 & 410 & 21 & - & - & - \\
\hline Glycine & 230 & 58 & 261 & 40 & 292 & 33 & 402 & 25 & * & - & - \\
\hline Threonine & 660 & 111 & 994 & 164 & 407 & 28 & 262 & 20 & $* * *$ & - & ** \\
\hline Alanine & 587 & 208 & 839 & 158 & 592 & 57 & 651 & 57 & - & - & - \\
\hline Arginine & 135 & 39 & 163 & 30 & 168 & 8 & 198 & 9 & - & - & - \\
\hline Valine & 219 & 62 & 241 & 38 & 146 & 6 & 129 & 6 & * & - & - \\
\hline Isoleucine & 104 & 29 & 122 & 24 & 77 & 5 & 73 & 4 & * & - & - \\
\hline Tryptophan & 91 & 27 & 72 & 10 & 76 & 4 & 70 & 6 & - & - & - \\
\hline Lysine & 574 & 126 & 752 & 116 & 1092 & 60 & 1159 & 50 & $* * *$ & - & - \\
\hline
\end{tabular}

${ }^{*} P<0.05,{ }^{* *} P<0.01,{ }^{* * *} P<0.001$.

†For details of diets and procedures, see p. 244.

$\ddagger$ Data were subjected to two-way ANOVA.

slower and it is possible that the availability of threonine influences growth in these latter stages. Threonine was the only amino acid which demonstrated a diet-induced decrease in both maternal serum and the fetal free amino acid pool. It should be stressed that the total pool of free amino acids in one entire fetus was measured. Despite the fact that the serum pool probably represents only $5 \%$ of the total free amino acids in the body, the similarity between the maternal and fetal threonine values, at each dietary protein level, and the magnitude of the fall in threonine is striking.

There are two principal metabolic fates for threonine: direct deamination by the enzyme threonine-serine dehydratase (EC 4.2.1.16) to yield 2-ketobutyric acid, or conversion by the enzyme L-threonine 3-dehydrogenase (EC 1.1.1.103) to 2-amino-3-ketobutyrate which is then cleaved to yield glycine + acetyl-CoA. The control of partitioning between these two pathways is not well understood. Threonine dehydratase is induced in rats by both high- and low-protein diets but the mechanism involved has not been established (Kang-Lee \& Harper, 1978; Bird \& Nunn, 1983). In the present study, threonine concentrations decreased by about $50 \%$ during pregnancy and by $75 \%$ (to $25 \%$ of normal) when the pregnant animal was fed on a low-protein diet. On the other hand pregnancy caused a $25 \%$ increase in free glycine concentrations in the animals fed on the $180 \mathrm{~g}$ protein $/ \mathrm{kg}$ diet, and an increase of nearly 2 -fold in the rats on low-protein intakes. The fall in circulating threonine concentrations may, therefore, be due to its metabolism to produce glycine. In the growing pig Ballevre et al. (1990) showed that up to $66 \%$ of threonine was oxidized and $76-80 \%$ of this oxidation was through glycine formation. Although usually considered as non-essential, glycine may become essential during pregnancy if the demands of the fetuses exceed the capacity for synthesis. This observation is not unique to rats, since glycine is considered to be potentially limiting during pregnancy in human subjects (Jackson et al. 1997). In recent studies of human populations Lenton et al. (1988) have demonstrated a significant inverse relationship between 5-L-oxo-proline, a marker of glycine insufficiency, and head circumference at birth. Glycine and its downstream metabolites, particularly methyl tetrahydrofolate, are important precursors for the synthesis of nucleoside bases and for the methylation of DNA. As well as nucleic acids, glycine is important in the synthesis of many compounds required for growth, both structural and functional e.g. collagen, haem, bile salts and glutathione (Jackson, 1991).

Threonine and glycine are also important in the metabolism of methionine and homocysteine. An identical diet, with additional methionine added to supplement the deficit in casein, was used by Langley-Evans et al. (1996) to demonstrate a link between the protein content of the diet and the induction of hypertension in the offspring. A constant methionine supplement $(5 \mathrm{~g} / \mathrm{kg})$ was used regardless of the protein content. Therefore in the animals fed on the lowprotein diets the supply of methionine remained constant and formed a higher proportion of the total amino acid supply. However there was no corresponding increase in circulating methionine concentrations, despite the fact that this excess methionine cannot be used for protein synthesis, suggesting that it was being metabolized. Girard-Globa et al. (1972) showed that feeding male weanling rats on a diet supplemented with $20 \mathrm{~g}$ methionine $/ \mathrm{kg}$ caused a drop in free threonine concentrations which was very similar to the change observed in the present experiments. The metabolism of methionine also transiently changed levels of the 
non-protein amino acid taurine suggesting that two alternative pathways are responsible for methionine oxidation. Initially methionine is metabolized via cystathionine and taurine until threonine-serine dehydratase has been induced as part of an alternative oxidative pathway (Girard-Globa et al. 1972). The decrease in free threonine may simply be a consequence of its oxidation by threonine-serine dehydratase induced by excess methionine. A change in taurine concentration has been observed in the serum of pregnant rats fed on low-protein diets and linked to changes in the ability of the pancreatic islets to release insulin (Reusens et al. 1995; Cherif et al. 1996). Because of the metabolic changes that occur when the mother is fed the deficient diet, the time allowed for adaptation before mating may be important in determining the final outcome.

There is also circumstantial evidence to suggest that changes in S-amino acid metabolism are responsible for the changes in fetal growth and survival. The fetus lacks cystathionine $\beta$-synthase (EC 4.2.1.22) and has no means to eliminate methionine and homocysteine. Methionine synthase (EC 2.1.1.13) progressively declines during gestation in a number of species (Gaull et al. 1973) while S-adenosyl homocysteine hydrolase (EC 3.3.1.1) remains relatively constant (VanAerts et al. 1995). The addition of homocysteine to embryo cultures in vitro leads increased growth because homocysteine is converted to S-adenosyl methionine by the fetus (VanAerts et al. 1994). An excess of methionine in the maternal diet may therefore be responsible for the early overgrowth of the fetuses from mothers fed on the $90 \mathrm{~g}$ protein/ $\mathrm{kg}$ diet because of its metabolism to homocysteine. There is clinical evidence that elevated homocysteine levels are associated with early pregnancy loss in human subjects (Wouters et al. 1993) and a further increase of homocysteine to toxic levels in the animals fed on the $60 \mathrm{~g}$ protein $/ \mathrm{kg}$ diet may be responsible for the reduction in the fetal number.

In conclusion, changes in the threonine-methioninehomocysteine group of amino acids early during pregnancy may be the nutritional trigger leading to the adverse effects of protein-deficiency. Methionine-homocysteine metabolism has already been shown to play a crucial role in the aetiology of neural-tube defects where disruption of folate metabolism leads to increases in homocysteine levels (Bakker \& Brandjes, 1997). These results suggest that this group of amino acids may also be involved in more subtle changes in fetal development leading to insulin resistance and hypertension later in life.

\section{Acknowledgements}

This work was supported by the Scottish Office Agriculture, Environment and Fisheries Department as part of the core funds of the Rowett Research Institute. C. A. was the recipient of a scholarship from the Greek State Foundation.

\section{References}

Adkins JS, Wertz JM \& Hove EL (1966) Influence of non-essential amino acids on growth of rats fed high levels of essential amino acids. Proceedings of the Society for Experimental Biology and Medicine 122, 519-523.
Ashford AJ \& Pain VM (1986) Effect of diabetes on the rates of synthesis and degradation of ribosomes in rat muscle and liver in vivo. Journal of Biological Chemistry 261, 4059-4065.

Bakker RC \& Brandjes DPM (1997) Hyperhomocysteinaemia and associated disease. Pharmacy World and Science 19, 126-132.

Ballevre O, Cadenhead A, Calder AG, Rees WD, Lobley GE, Fuller MF \& Garlick PJ (1990) Quantitative partition of threonine oxidation in pigs: effect of dietary threonine. American Journal of Physiology 259, E483-E491.

Barker DJ (1995) Fetal origins of coronary heart disease. British Medical Journal 311, 171-174.

Bird MI \& Nunn PB (1983) Metabolic homeostasis of L-threonine in the normally fed rat. Importance of liver threonine dehydrogenase activity. Biochemical Journal 214, 687-694.

Burton K (1956) A study of the conditions and mechanisms of the diphenylamine reaction for the colorimetric estimation of deoxyribonucleic acid. Biochemical Journal 62, 315-318.

Cherif H, Reusens B, Dahri S, Remacle C \& Hoet J-J (1996) Stimulatory effects of taurine on insulin secretion by fetal rat islets cultured in vitro. Journal of Endocrinology 151, 501-506.

Davison AN \& Dobbing J (1966) Myelination as a vulnerable period in brain development. British Medical Bulletin 22, 4044.

Desai M, Crowther NJ, Lucas A \& Hales CN (1996) Organselective growth in the offspring of protein-restricted mothers. British Journal of Nutrition 76, 591-603.

Desai M, Crowther NJ, Ozanne SE, Lucas A \& Hales CN (1995) Adult glucose and lipid metabolism may be programmed during fetal life. Biochemical Society Transactions 23, 331-335.

Fleming JV, Hay SM, Harries DN \& Rees WD (1998) The effects of nutrient deprivation and differentiation on the expression of growth arrest genes (gas and gadd) in F9 embryonal carcinoma cells. Biochemical Journal 330, 573-579.

Gaull GE, von Berg W, Raiha NCR \& Sturman JA (1973) Development of methyltransferase activities of human fetal tissues. Pediatric Research 7, 527-533.

Girard-Globa A, Robin P \& Forestier M (1972) Long-term adaptation of weanling rats to high dietary levels of methionine and serine. Journal of Nutrition 102, 209-218.

Godfrey KM, Forrester T, Barker DJ, Jackson AA, Landman JP, Hall JS, Cox V \& Osmond C (1994) Maternal nutritional status in pregnancy and blood pressure in childhood. British Journal of Obstetrics and Gynaecology 101, 398-403.

Harper AE (1974) 'Non essential' amino acids. Journal of Nutrition 104, 965-967.

Jackson AA (1991) The glycine story. European Journal of Clinical Nutrition 45, 59-65.

Jackson AA, Persaud C, Werkmeister G, McClelland ISM, Badaloo A \& Forrester T (1997) Comparison of urinary 5-Loxoproline (L-pyroglutamate) during normal pregnancy in women in England and Jamaica. British Journal of Nutrition 80, 51-55.

Kang-Lee YAE \& Harper AE (1978) Threonine metabolism in vivo: effect of threonine intake and prior induction of threonine dehydratase in rats. Journal of Nutrition 108, 163-175.

Langley SC \& Jackson AA (1994) Increased systolic blood pressure in adult rats is altered by in utero exposure to maternal low protein diets. Journal of Nutrition 124, 1588-1596.

Langley-Evans SC, Browne RF \& Jackson AA (1994) Altered glucose tolerance in rats exposed to maternal low protein diets in utero. Comparative Biochemistry and Physiology 109A, 223229.

Langley-Evans SC, Gardner DS \& Jackson AA (1996) Association of disproportionate growth of fetal rats with raised systolic blood pressure in later life. Journal of Reproduction and Fertility 106, 307-312. 
Lenton C, Ali Z, Persaud C \& Jackson AA (1998) Infants in Trinidad excrete more 5-L-oxoproline (L-pyroglutamic acid) in urine than infants in England: an environmental not ethnic difference. British Journal of Nutrition 80, 51-55.

Lowry OH, Rosebrough NJ, Farr AL \& Randall RJ (1951) Protein measurement with the Folin phenol reagent. Journal of Biological Chemistry 193, 265-272.

Naismith DJ \& Morgan BLG (1976) The biphasic nature of protein metabolism during pregnancy in the rat. British Journal of Nutrition 36, 563-566.

Palmer RM, Thom A \& Flint DJ (1996) Repartitioning of maternal muscle protein towards the fetus induced by a polyclonal antiserum to rat GH. Journal of Endocrinology 151, 395-400.

Phillips DI, Barker DJ, Hales CN, Hirst S \& Osmond C (1994) Thinness at birth and insulin resistance in adult life. Diabetologia 37, 150-154.

Remesar X, Lopex-Tejero D \& Pastor-Anglada M (1987) Some aspects of amino acid metabolism in the rat fetus. Comparative Biochemistry and Physiology 88B, 719-725.

Reusens B, Dahri S, Snoeck A, Bennis-Taleb N, Remacle C \& Hoet J-J (1995) Long term consequences of diabetes and its complications may have a fetal origin: experimental and epidemiological evidence. In Diabetes: Nestlé Nutrition Workshop Series, vol. 35, pp. 187-198 [RM Cowett, editor]. New York, NY: Raven Press.
Rowe PB \& McEwen SE (1983) De novo purine synthesis in cultured rat embryos undergoing organogenesis. Proceedings of the National Academy of Sciences USA 80, 7333-7336.

Snoeck A, Remacle C, Reusens B \& Hoet JJ (1990) Effect of a low protein diet during pregnancy on the fetal rat endocrine pancreas. Biology of the Neonate 57, 107-118.

VanAerts LAGJM, Blom HJ, DeAbreu RA, Trijbels FJM, Eskes TKAB, Copius Peereboom-Stegeman JHJC \& Noordhoek J (1994) Prevention of neural tube defects by and toxicity of Lhomocysteine in cultured postimplantation rat embryos. Teratology 50, 348-360.

VanAerts LAGJM, Poirot CM, Herberts CA, Blom HJ, DeAbreu RA, Trijbels FJM, Eskes TKAB, Copius Peereboom-Stegeman JHJC \& Noordhoek J (1995) Development of methionine synthase, cystathionine- $\beta$-synthase and S-adenosyl-homocysteine hydrolase during gestation in rats. Journal of Reproduction and Fertility 103, 227-232.

Widdowson EM \& McCance RA (1963) Effects of finite periods of under-nutrition at different ages on the composition and subsequent development of the rat. Proceedings of the Royal Society Series B 158, 329-342.

Wouters MGAJ, Thomas CMG, Boers GHJ, Borm GF, Blom HJ, Steegers-Theunisen RPM, Trijbels FJM \& Eskes TKAB (1993) Hyperhomocysteinemia: a risk factor in women with unexplained recurrent early pregnancy loss. Fertility and Sterility 60, 820825. 